\title{
New marine Thinophilus species (Diptera: Dolichopodidae: Hydrophorinae) from the Thai Andaman Sea coast and new records from peninsular Thailand
}

\author{
Abdulloh SAMOH ${ }^{1}$, Chutamas SATASOOK ${ }^{2} \&$ Patrick GROOTAERT $^{3, *}$ \\ ${ }^{1,2}$ Princess Maha Chakri Sirindhorn Natural History Museum (PSUNHM), Faculty of Science, \\ Prince of Songkla University, Kho Hong, Hat Yai, Songkhla, 90110, Thailand. \\ ${ }^{3}$ Entomology Research Unit, Royal Belgian Institute of Natural Sciences (RBINS), Vautierstraat 29, \\ B-1000, Brussels, Belgium. \\ ${ }^{*}$ Corresponding author: Patrick.Grootaert@naturalsciences.be \\ ${ }^{1}$ Email: abdulloh.sam@psu.ac.th \\ 2Email: flywizme@gmail.com \\ ${ }^{1}$ urn:lsid:zoobank.org:author:A18861BF-9717-4661-94AD-2599CEE6E9B7
${ }^{2}$ urn:Isid:zoobank.org:author:97FDD929-CC25-400F-88B5-48D695662D75
${ }^{3}$ urn:1sid:zoobank.org:author:B80BC556-9087-4D0D-9D69-7FA9BE5779C4
}

\begin{abstract}
Three new species of Thinophilus Wahlberg, 1844 are described from marine sites on the Andaman Sea coasts in peninsular Thailand: T. inaequalis Samoh \& Grootaert sp. nov. belonging to the 'Thinophilus simplex-group' sensu Grootaert, 2018, T. plektron Samoh \& Grootaert sp. nov., an unplaced species characterised by a long flattened apical spur on the hind tibia, and T. subapicalis Samoh \& Grootaert sp. nov. belonging to the 'Thinophilus spinatus-group' sensu Grootaert, 2018. New records are given for following species occurring in peninsular Thailand: T. apicatus Grootaert, 2018, T. chaetulosus Grootaert, 2018, T. clavatus Zhu, Yang \& Masunaga, 2006, T. evenhuisi Grootaert, 2018, T. lenachanae Grootaert, 2018, T. longicilia Evenhuis \& Grootaert, 2002, T. nigrilineatus Grootaert, 2018, T. simplex Grootaert, 2018, T. superbus Grootaert, 2018, and T. yeoi Grootaert, 2018.
\end{abstract}

Keywords. Hydrophorinae, mangrove, new species, Thai Peninsula, Thinophilus.

Samoh A., Satasook C. \& Grootaert P. 2019. New marine Thinophilus species (Diptera: Dolichopodidae: Hydrophorinae) from the Thai Andaman Sea coast and new records from peninsular Thailand. European Journal of Taxonomy 505: 1-20. https://doi.org/10.5852/ejt.2019.505

\section{Introduction}

The dolichopodid genus Thinophilus Wahlberg, 1844 is easily recognised by its almost circular third antennal segment with a dorsal or subapical arista, the first antennal segment is dorsally bare, vein $\mathrm{M}$ is generally straight or at most slightly undulating to wing tip. Males have a long coiled phallus hidden between the surstyli and the cerci. They possess a variety of typical male secondary sexual characters. For example, in T. parmatus Grootaert \& Meuffels, 2001 and T. parmatoides Samoh et al., 2017 the second 
segment of the mid tarsus is dorsally enlarged into a dark brown lobe (a small shield-like protuberance) (Grootaert \& Meuffels 2001), while in the case of T. superbus Grootaert, 2018, the hind tibia bears a very long dorsal apical bristle as long as the tibia itself. Several species bear long ventral bristles on the fore femur. In T. longicilia Evenhuis \& Grootaert, 2002 and T. comatus Grootaert, 2018 the fore and mid femora as well as the tibiae bear very long soft ventral bristles. However, there are also species such as T. meieri Grootaert, 2018 that bear very long bristles on the hind legs. It is likely that these bristles play a role during mating as shown in sepsid flies (Puniamoorthy et al. 2009). Some Thinophilus even have all three pairs of legs adorned. These characters likely play an important role in sexual selection (female choice/male-male interactions) and it is assumed that a rapid evolution can take place in these characters because they are under a strong selection pressure.

Thinophilus in Southeast Asia thrives in marine habitats (Grootaert \& Meuffels 2001; Evenhuis \& Grootaert 2002; Samoh et al. 2015, 2017; Grootaert 2018), where they are often found on rocky shores, but most species are found in front mangroves or follow the creeks inside the mangrove. A few species are non-marine, such as T. mekongensis Grootaert, 2017, and the very common and widespread T. nitens Grootaert \& Meuffels, 2001 and T. setiventris Grootaert \& Meuffels, 2001.

Thinophilus belongs to the subfamily Hydrophorinae Lioy, 1864 and the actual known number of species is around 146 species worldwide (Negrobov et al. 2016). The first Thai species were recorded by Grootaert \& Meuffels (2001): T. nitens, T. parmatus, and T. setiventris. However, an additional eight new species of true marine Thinophilus have been described recently by Samoh et al. (2017). They comprise T. boonrotpongi Samoh et al., 2017, T. langkawensis Samoh et al., 2017, T. minutus Samoh et al., 2017, T. parmatoides, T. parvulus Samoh et al., 2017, T. spinatus Samoh et al., 2017, T. spinatoides Samoh et al., 2017, and T. variabilis Samoh et al., 2017. Here, we describe three new species thus bringing the total number for Southeast Asia to 57 species.

\section{Material and methods}

The new species were collected in three localities with the following characteristics (Fig. 1): the sandy-banks of brackish water swamps on Phra Thong Island (Koh Phra Thong), Phang Nga province $\left(9^{\circ} 03^{\prime} 29.5^{\prime \prime} \mathrm{N}, 98^{\circ} 15^{\prime} 02.6^{\prime \prime} \mathrm{E}\right)$, a mangrove at Phang Nga bay $\left(8^{\circ} 24^{\prime} 02.5^{\prime \prime} \mathrm{N}, 98^{\circ} 30^{\prime} 38.6^{\prime \prime} \mathrm{E}\right)$ and a mangrove creek near Bang Ben Sea coast (9॰36'32.9" N, 98 29'12.6" E). The new records for the Thai fauna were collected during earlier surveys in peninsular Thailand (Samoh et al. 2017). The specimens were collected by sweep netting and hand collecting by using plastic tubes. All material is preserved in $70 \%$ ethanol for further external morphology and molecular study.

All type material is deposited in the collections of the Princess Maha Chakri Sirindhorn Natural History Museum (PSUNHM), Prince of Songkla University, Faculty of Science, Hat Yai, Songkhla, Thailand. A few voucher specimens are deposited at the Royal Belgian Institute of Natural Sciences, Brussels, Belgium (RBINS). Figured specimens are labeled as 'PSUZCDIP000' (Prince of Songkla University zoological Collection Diptera).

A focus stacking technique (see full details in Brecko et al. 2014) was used to photograph the specimens. The high-resolution pictures were stacked using Zerene Stacker software. 


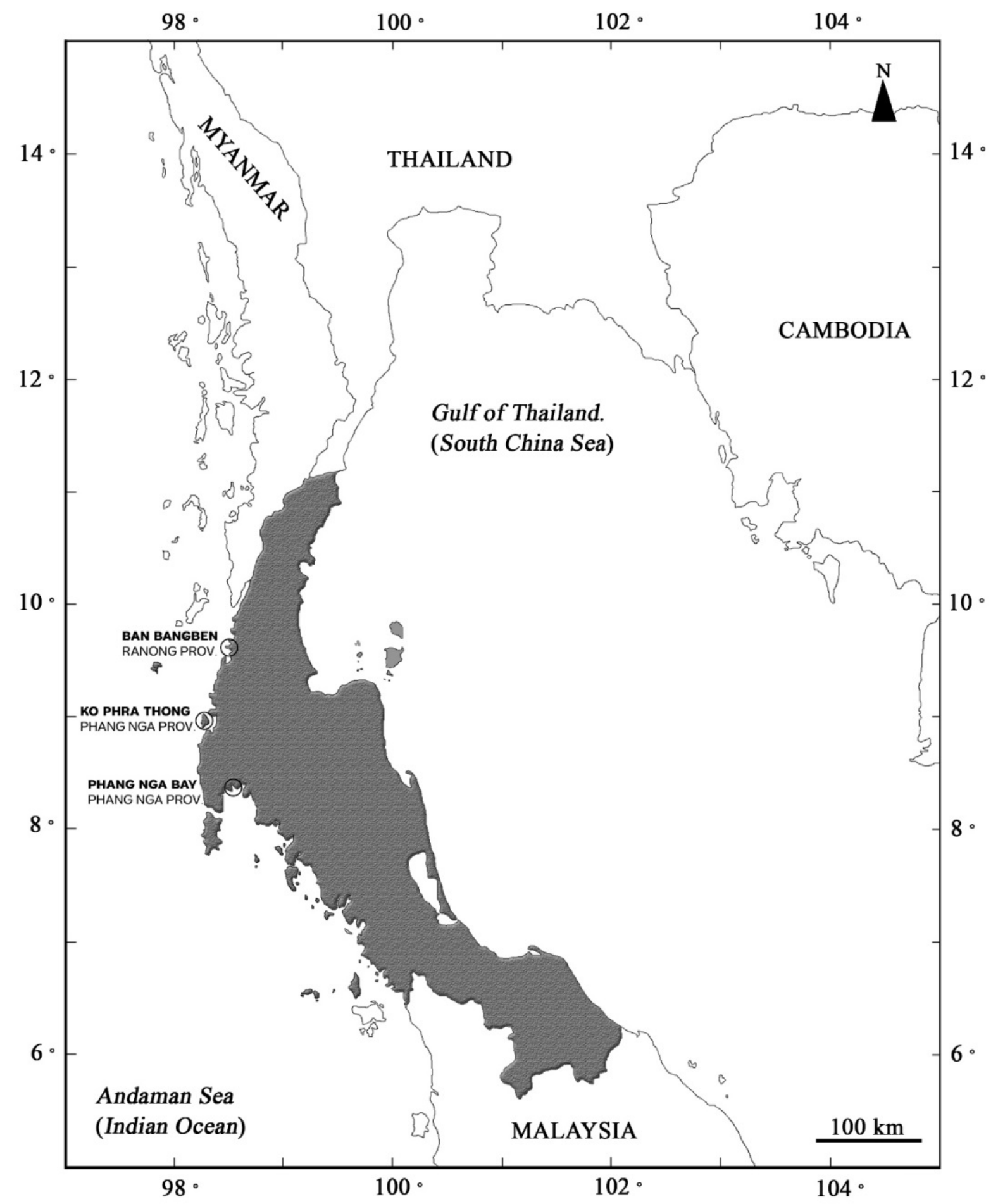

Fig. 1. Map of peninsular Thailand which is bordered by the Gulf of Thailand, a part of the South China Sea in the East and the Andaman Sea (Indian Ocean) in the West. The provenance of the three new species is indicated. 


\title{
Results
}

\section{New species of marine Thinophilus in Thailand}

\author{
Class Insecta Linnaeus, 1758 \\ Order Diptera Linnaeus, 1758
}

Superfamily Empidoidea Latreille, 1804

Family Dolichopodidae Latreille, 1809

Subfamily Hydrophorinae Lioy, 1864

Thinophilus Wahlberg, 1844

Thinophilus Wahlberg, 1844: 37. Type species: Rhaphium flavipalpe Zetterstedt,1843 (monotypy).

Parathinophilus Parent, 1932: 161. Type species: Parathinophilus expolitus Parent, 1932 (monotypy).

Thinophilus inaequalis Samoh \& Grootaert sp. nov. urn:lsid:zoobank.org:act:04B69217-31C2-4DB8-86CB-E2855CC47954

Figs 2-4

\section{Diagnosis}

A small species from the 'Thinophilus simplex-group'. Fore coxa entirely yellow with a single short black bristle near middle. Legs yellow, but apical tarsomere of all legs black. Fore femur with a few long ventral bristles near base and a row of about eight posteroventral bristles in apical $2 / 3$. Mid femur with a

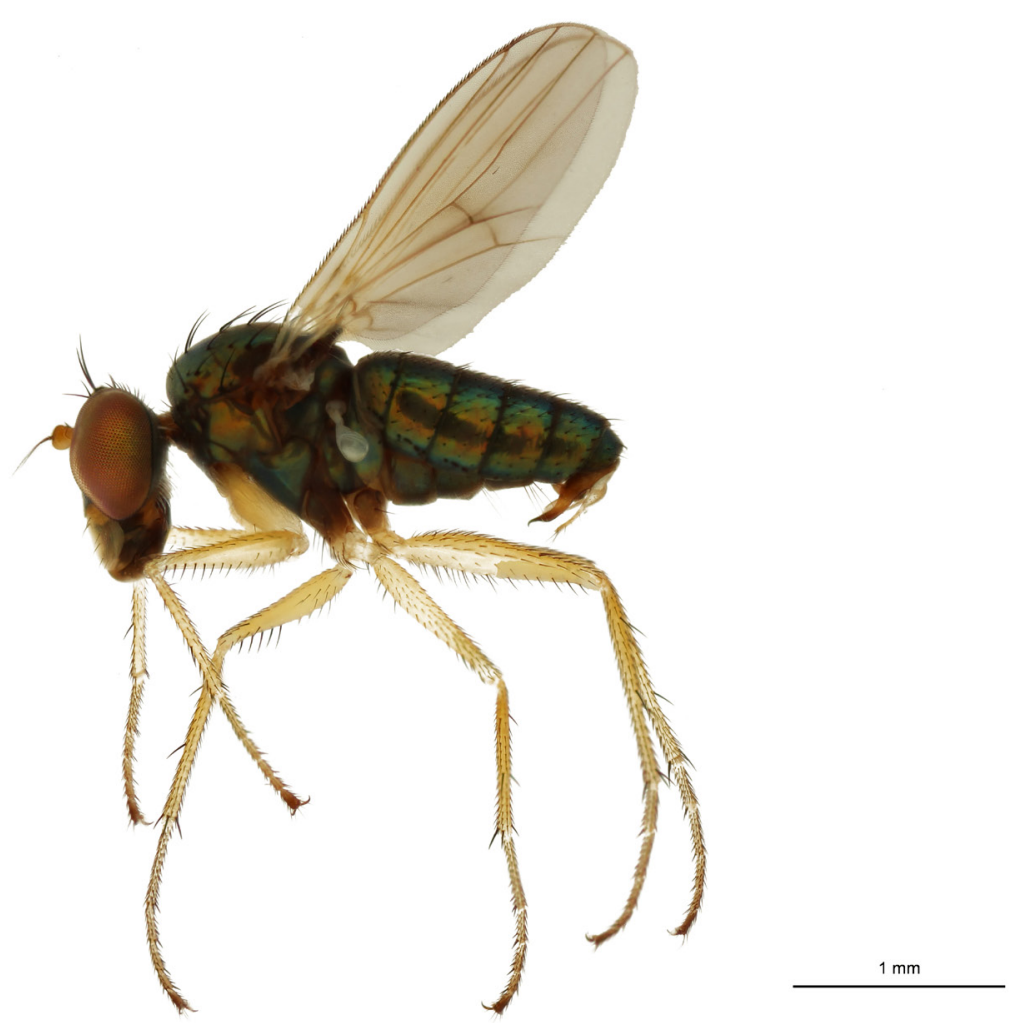

Fig. 2. Thinophilus inaequalis Samoh \& Grootaert sp. nov. Male habitus (Abdulloh Samoh leg., PSUNHM (PSUZCDIP0011)). 
row of five to six strong black bristles in apical third. Hind femur with three to four ventral bristles on basal quarter and a row of fine anteroventral bristles over entire length about half as long as femur is wide. Sternite 3 and 4 with very long pale bristles at side near tip. Left surstylus pointed, right surstylus blunt.

\section{Etymology}

The name 'inaequalis' alludes to the asymmetric surstyli: the left surstylus is pointed while the right surstylus has a blunt tip.

\section{Type material}

\section{Holotype}

THAILAND - Phang Nga Prov. • 1 ơ; Ko Phra Thong, Andaman Sea; 903'58.6" N, 98¹5'09.9" E; 25 Apr. 2018, A. Samoh leg.; sweep netting; PSUNHM.

\section{Paratypes}

THAILAND - Phang Nga Prov. • $12 \hat{\jmath}, 14$ $q$; ; same data as for the holotype; PSUNHM $(1 \hat{\sigma}$ PSUZCDIP0011, 1 q PSUZCDIP0012) • Ko Phra Thong, Andaman Sea; 903'29.5" N, 98 15'02.4" E;

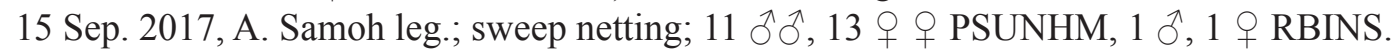

\section{Description}

\section{Male (Fig. 2)}

Measurements. Small species. Body $2.5-2.7 \mathrm{~mm}$; wing $2.2-2.6 \mathrm{~mm}$.

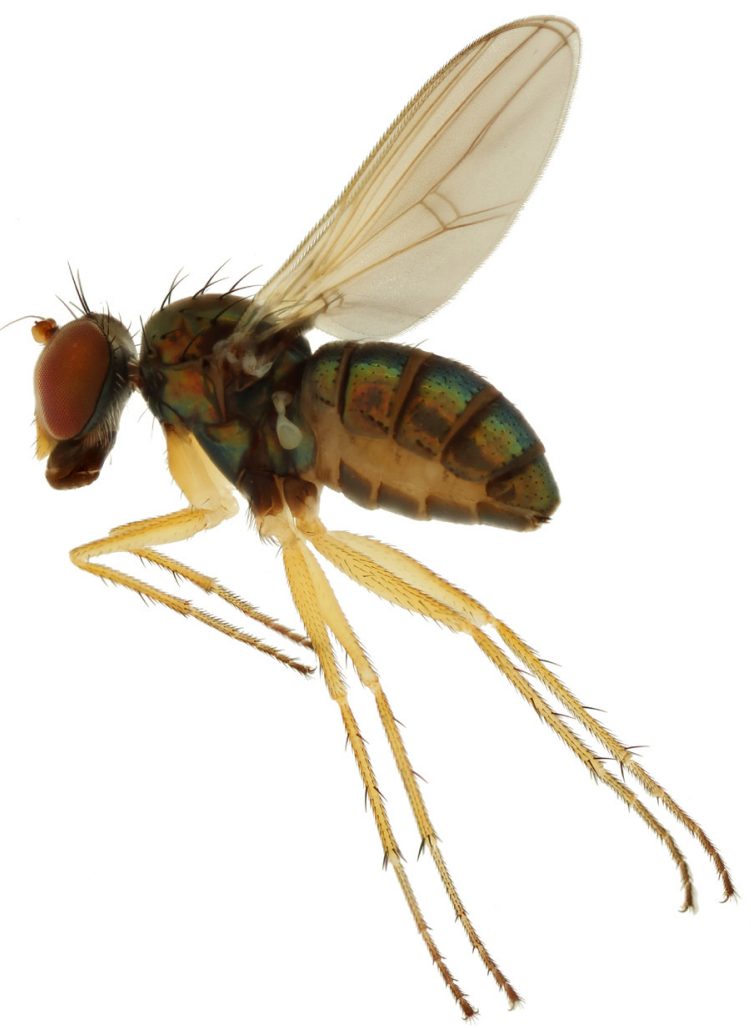

Fig. 3. Thinophilus inaequalis Samoh \& Grootaert sp. nov. Female habitus (Abdulloh Samoh leg., PSUNHM (PSUZCDIP0012)). 
HEAD. Ocellar bristles long, vertical bristles half as long as ocellars. Postvertical bristle indistinct. Upper postoculars small, black, uniseriate; lower postoculars a little longer and paler than upper, uniseriate, but with a few longer bristles behind the row. Antenna yellow, postpedicel dusky yellow and arista black. Palpus large, about half as long as height of an eye, covered with a few thin bristles. Proboscis black, rather long.

THORAX. Shining metallic green. Four equally long dorsocentrals preceded by a small bristle. Wing clear with pale yellowish veins. Squama white with a few white cilia. Haltere white.

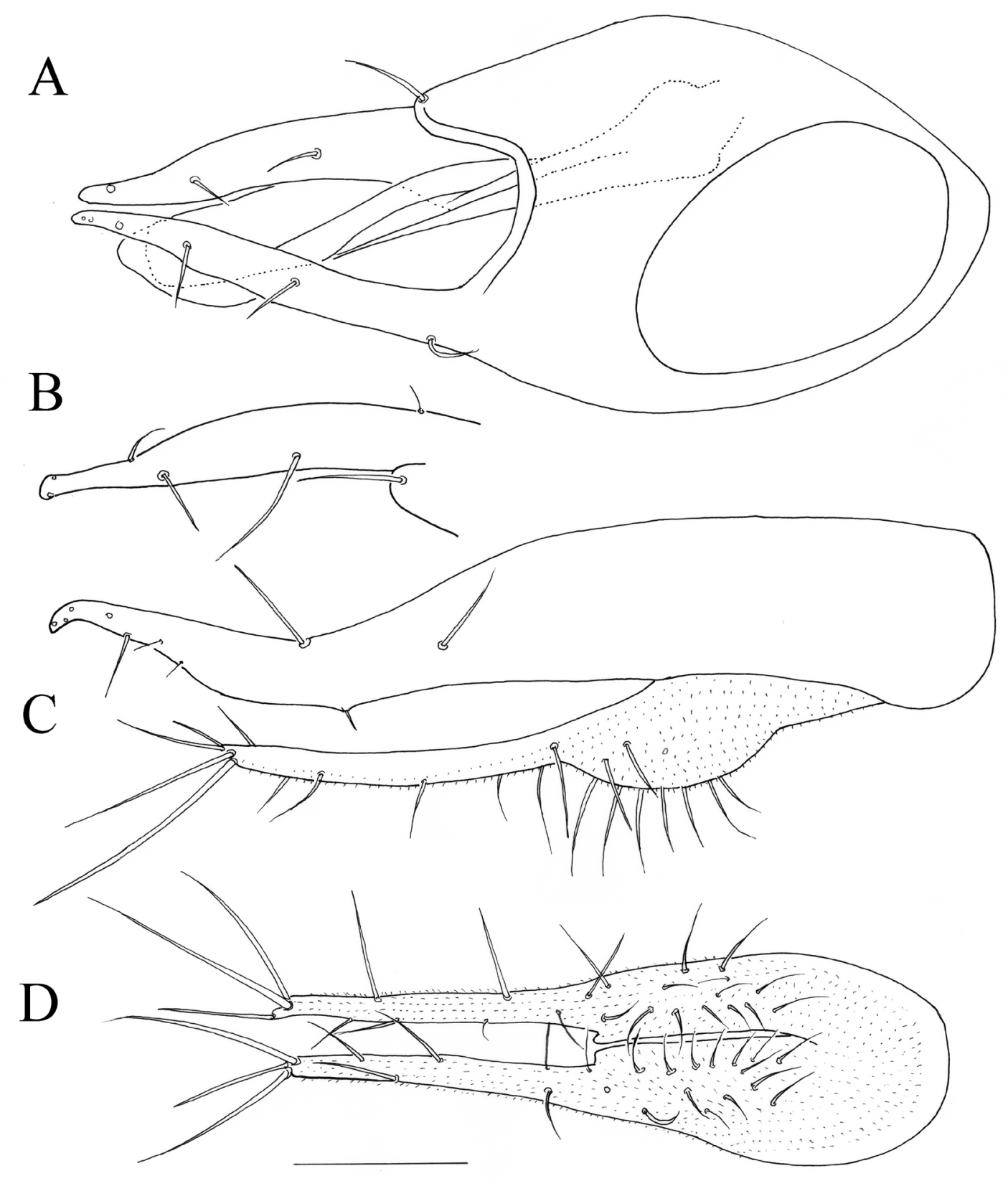

Fig. 4. Thinophilus inaequalis Samoh \& Grootaert sp. nov. Male terminalia (Abdulloh Samoh leg., PSUNHM (PSUZCDIP0011)). A. Ventral view on epandrium. B. Tip of right surstylus. C. Lateral view on left side of epandrium with a pointed left surstylus. D. Dorsal view on cerci. Scale $=0.1 \mathrm{~mm}$. 
Colour of Legs. Yellow, including fore coxa, but mid and hind coxae brown. Apical tarsomere of all legs black.

FoRE LEG. Coxa with a single short black bristle near middle. Femur with a few long ventral bristles near base and a row of about eight posteroventral bristles in apical $2 / 3$. Tibia with a short dorsal and posteroventral bristle near middle, lacking spine-like ventral bristles.

MID LEG. Coxa with one long exterior. Femur with a row of five to six strong black bristles in apical third. Tibia with one anterodorsal and one posterodorsal bristle at basal quarter and one anterodorsal and one posterodorsal bristle just beyond middle.

HIND LEG. Coxa with an exterior bristle. Femur with about three to four ventral bristles on basal quarter and a row of fine anteroventral bristles over entire length about half as long as width of femur. One distinct anterior bristle before middle and a longer anterodorsal on apical third. Tibia with two anterodorsal and two dorsal bristles.

АвDOMEn. Tergites subshining metallic greenish black, set with short black bristles. Sternite 3 and 4 with long, fine pale bristles at side near tip. Terminalia (Fig. 4). Cerci widely separated over more than half their length, joining at base but not fused (Fig. 4D). Cercus with only a few long bristle at apex, the rest of the cercus sparsely set with bristles. Left surstylus pointed (Fig. 4C), right surstylus blunt (Fig. 4B). A distinct epandrial bristle present (Fig. 4C).

Female (Fig. 3)

Body 2.4-2.9 mm; wing 2.2-2.4 mm. Similar to male but lacking the posteroventral bristle on the fore femur while posteroventrals in apical half of mid femur are present. Hind femur also lacking the row of long ventral and anteroventral bristles. Apical three tarsomeres of all legs more dusky than in male and thus tarsomere 5 is not so contrastingly darkened. Sternites with minute white hairs only.

\section{Comments}

The new species belongs to the 'Thinophilus simplex-group' sensu Grootaert (2018). Having entirely yellow fore coxa with only a single short black bristle, the new species runs to couplet 27 leading to T. evenhuisi Grootaert, 2018 and T. minor Grootaert, 2018. It is, however, very distinct from both species in that $T$. evenhuisi has two very long, black ventral bristles near middle of the fore femur (twice as long as femur is wide), not present in the new species. Thinophilus minor has a row of very long ventral bristles on the fore tibia.

Thinophilus plektron Samoh \& Grootaert sp. nov. urn:1sid:zoobank.org:act:B560D3B5-AD31-43C2-9C67-10438E4C7104

Figs $5-7$

\section{Diagnosis}

A large species with all coxae black and fore coxa bearing long white bristles. All femora strongly thickened, hind femur strongest. Hind tibia with a long, blunt flattened apical spur.

\section{Etymology}

The specific name is from the Greek 'plektron' ('thing to strike with': cock's spur, pick for a lyre) alluding to the apical spur on the hind tibia. It is used as a noun in apposition. 


\section{Type material}

\section{Holotype}

THAILAND - Ranong Prov. • 1 đ̊; Khlong Chanut, Ban Bang Ben, Kapoe district, Andaman Sea; 9³6'32.9" N, 98²9'12.6" E; 12 Jul. 2018; A. Samoh leg.; sweep netting; PSUNHM.

\section{Paratypes}

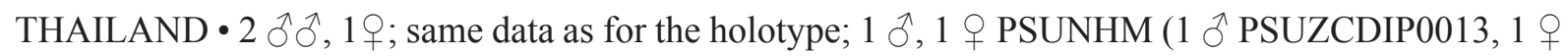
PSUZCDIP0014), 1 ๙ RBINS.

\section{Description}

\section{Male (Fig. 5)}

MeAsurements. Large species. Body $7 \mathrm{~mm}$; wing $6 \mathrm{~mm}$.

Head. Both frons and face wide, subshining bluish. Ocellars long, verticals also long, about $3 / 4$ of ocellars. Postverticals as long as verticals (Fig. 5). Postoculars black, uniseriate above, long, white, and multiseriate below. Clypeus protruding over the robust proboscis that is about half as long as the eye height. Palpus yellow, but black at base and covered with long black bristles. Antenna yellowish, with all segments darkened above. Scape longer than pedicel, the latter with long dorsal bristle and a few short bristles below. Postpedicel slightly longer than high, triangular in lateral view, with a blunt tip (Fig. 5).

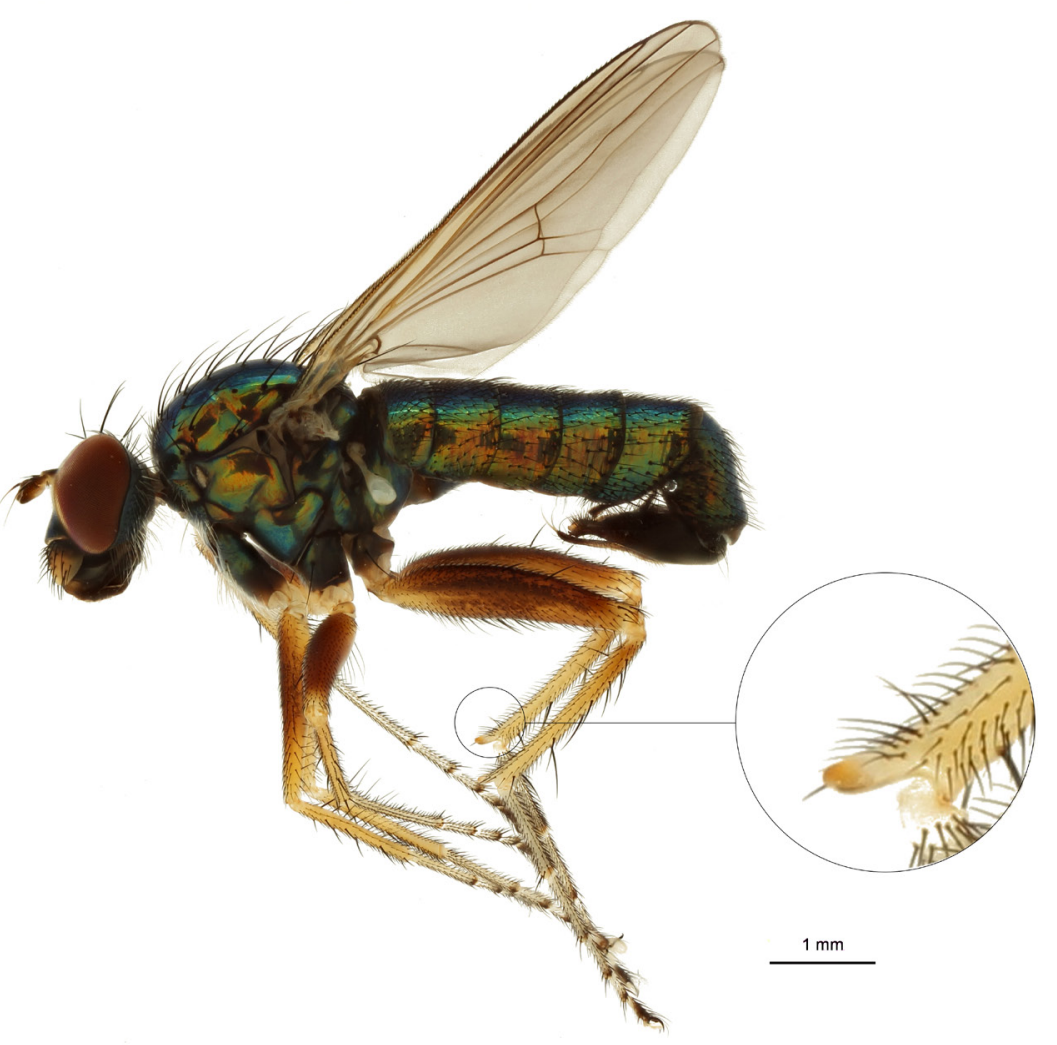

Fig. 5. Thinophilus plektron Samoh \& Grootaert sp. nov. Male habitus (Abdulloh Samoh leg., PSUNHM (PSUZCDIP0013)). 
THORAX. Black in ground-colour, subshining (faint cover of dusting), and with a greenish bluish metallic shine. All bristles black and long. Six equally long dorsocentrals. Upper and lower propleural bristles densely set, white. Upper propleurals shorter than lower.

Colour of LEgs. Largely yellowish. All coxae black with extreme tip yellowish. All trochanters contrastingly pale (whitish) with a black stripe at connection with femur. All femora darkened brown above and laterally, ventrally more yellowish. All tibiae yellow. All tarsi whitish yellow, with extreme tips of all tarsomeres black above (ventrally white). Apical tarsomere of all legs entirely black above.

Fore LEG. Coxa with only white bristles, including the apicals. Longest bristles with long white bristles near base. Femur swollen, with a double row of ventral bristles about half as long as width of femur; a row of posteroventrals with a few longer bristles near base. Most basal bristle longer than femur width. Fore tibia with a row of long ventral bristles, the longest near base, strong and three times as long as width of tibia. The bristles decrease in length toward tip of tibia; the row continues on the first tarsomere. A set of six strong dorsal and posterodorsal bristles on median third of tibia.

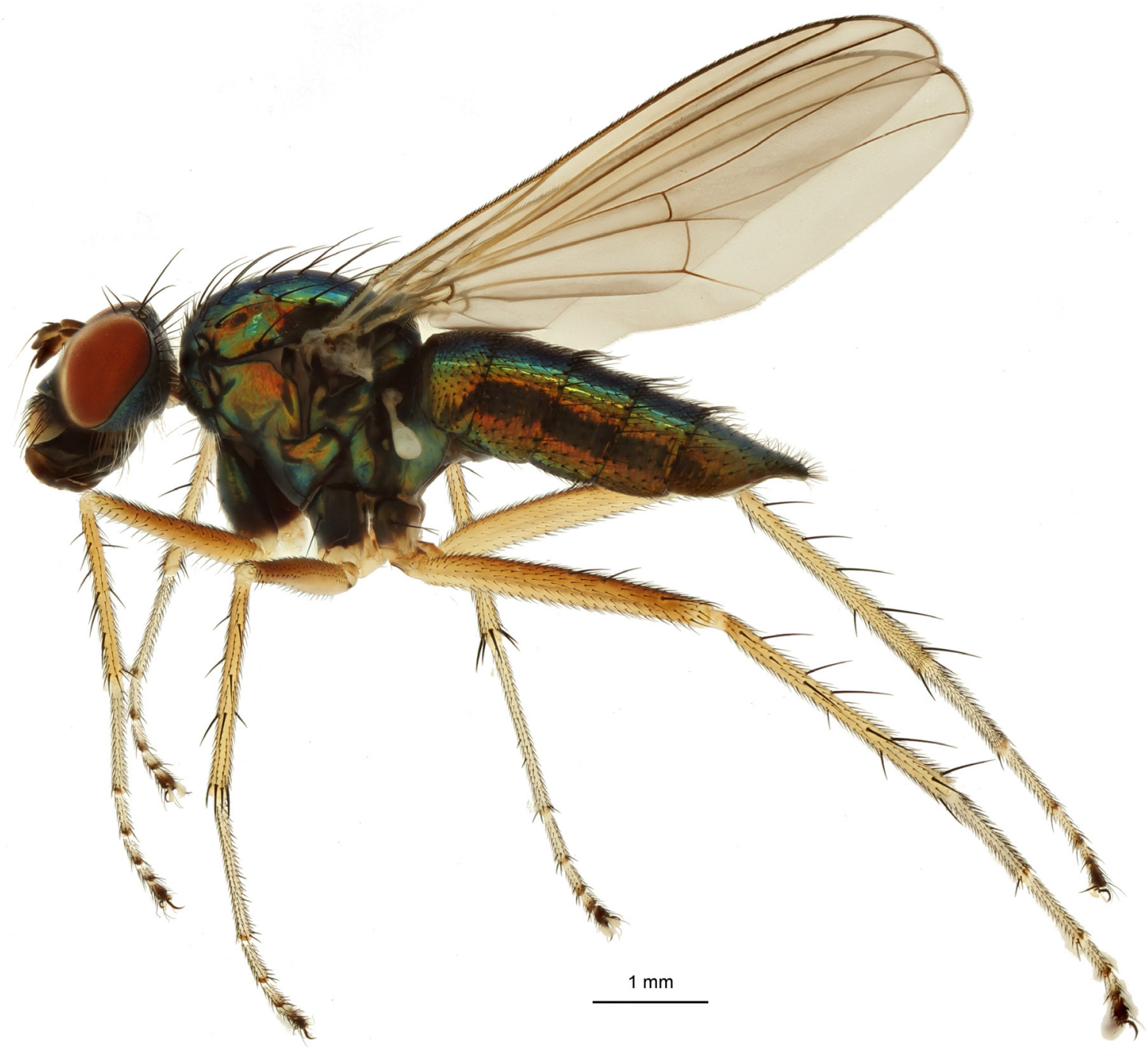

Fig. 6. Thinophilus plektron Samoh \& Grootaert sp. nov. Female habitus (Abdulloh Samoh leg., PSUNHM (PSUZCDIP0014)). 
MID LEG. Coxa with a long black exterior. Femur as wide as fore femur. Anteroventrally with multiple rows of long black bristles in basal $3 / 4$. Row of posteroventral long bristles in basal half, longest near base of femur, nearly as long as femur width, the bristles become gradually shorter toward apex. Tibia as long as femur, with a ventral row of short spine-like bristles over the entire length. A strong black curved spine at tip. Tarsomere 1 very long, nearly 1.5 times as long as all following tarsomeres together.

HIND LEG. Coxa with a long exterior. Femur broader and longer than mid femur; spindle shaped; with four strong dorsal black bristles in apical half; ventrally densely set with bristles, a patch of longer bristles near middle. Tibia ending in a long flattened apical spur as long as tibia width at that point; ventrally and posteroventrally with a row of fine bristles over entire length, nearly as long as tibia width; near base with two to three long black ventral to posteroventral bristles. Dorsally with unusually long dorsal bristles.

WING. With a faint brownish tinge, veins pale brownish in basal half, black in apical half. Squama white with short white cilia. Haltere white.

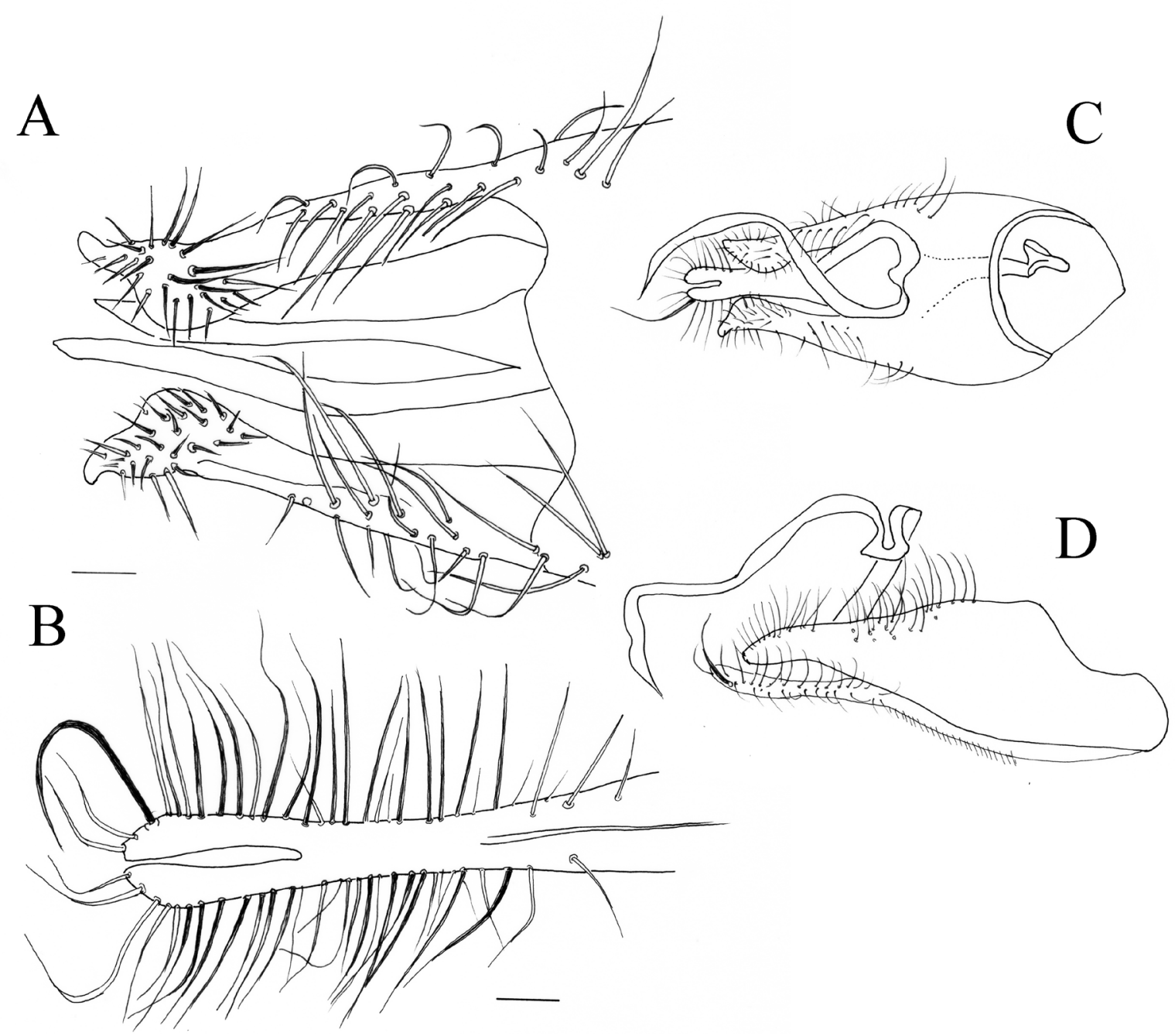

Fig. 7. Thinophilus plektron Samoh \& Grootaert sp. nov. Male terminalia (Abdulloh Samoh leg., PSUNHM (PSUZCDIP0013)). A. Ventral view of tips of surtstyli. B. Dorsal view of tip of fused cerci. C. Ventral view of epandrium. D. Lateral view on epandrium. Scale $=1 \mathrm{~mm}$. 
AвDOMEN. Subshining metallic green, tergites densely covered with short black bristles, except for the sides of tergite 5 that have very long bristles. Posteromarginal bristles a little longer. Sternites with short bristles on basal segments. Sternite 5 densely set with bristles, basal bristles even spine-like. Terminalia (Fig. 7) black. Cercus pale at base, darkened at tip, covered with long pale bristles and a long strong black bristle near tip (Fig. 5B). Cerci separated near tip over a short distance and eventually fused (Fig. 7B). Phallus long, wide, black (Figs 5, 7C-D). Apex of surstylus widened and ventrally covered over the whole length with long black bristles (Fig. 7A). Epandrial lobe indistinct and no epandrial bristle distinct from other bristles.

Female (Fig. 6)

Body $6.7 \mathrm{~mm}$; wing $7.3 \mathrm{~mm}$. Resembling male, but all femora slender and bristling on legs simple. No apical spur on hind tibia.

\section{Comments}

Having entirely black fore coxa with white bristles, the new species will lead to T. boonrotpongi Samoh et al., 2017 in couplet no. 5 of the key in Grootaert (2018). Additionally, in the latter species, the fore femur also has white bristles mixed with black ventral bristles. In the new species, there are only black ventral bristles on the fore femur. The most distinctive and hitherto unique character in oriental Thinophilus is the long flattened apical spur on the hind tibia.

At first sight, the new species seems to belong to the 'Thinophilus murphyi-group' sensu Grootaert (2018). This is a group of medium to large-sized, robust species with large mouthparts. The cerci are long and separated apically. The arista is partly white on the apex. However, the new species differs in several aspects. The tip of the cercus is not fused at the extreme tip, but shortly behind the tip. The arista is indeed paler but not white on the apex. The bristling of the surstylus is unusually long and dense and this is a situation we find in the Chinese species T. zhuae Grootaert et al., 2017, but in this species the cerci are much wider, keel-shaped and seem to form a protection for the phallus and surstyli. In the latter species, the tip of the surstylus is also set with numerous bristles. In the present species, the bristles are denser set over the entire length of the surstylus. Thus, we consider this species as yet unplaced.

The new species resembles also superficially T. nigrilineatus Grootaert, 2018, but the hind femur in the latter is not as strongly swollen as in the new species and a little twisted. The shape of the cerci is also different.

Thinophilus subapicalis Samoh \& Grootaert sp. nov. urn:1sid:zoobank.org:act:BF708B92-B7E5-44EB-B0AD-0CF1773CECC7

Figs $8-10$

\section{Diagnosis}

A small sized species of the 'Thinophilus spinatus-group' with black fore coxa. Hind tibia in male with a very long pre-apical dorsal bristle as long as hind tibia. Fore tibia with a ventral protuberance just beyond middle bearing two long ventral bristles. Mid tibia with five long ventral interspaced bristles more than three times as wide as tibia. Mid tarsomeres 2 and 3 flattened, the latter orange. Hind tarsomere 2 with two very long ventral bristles near base.

\section{Etymology}

The name 'subapicalis' refers to the subapical position of the very long subapical bristle on the hind tibia. 


\section{Type material}

\section{Holotype}

THAILAND - Phang Nga Prov. 1 đ ; Meuang district, Khlong Nai Ngop, Ban Tha Dan, Andaman Sea; 8²4'02.5" N, 98³0'38.6" E; 22 Mar. 2018; A. Samoh leg.; sweep netting; PSUNHM (PSUZCDIP0015).

\section{Paratypes}

THAILAND • 3 + $\odot$; same data as for the holotype; PSUNHM (1 $q$ PSUZCDIP0016).

\section{Description}

\section{Male (Fig. 8)}

MEASUREMENTS. Body $3.2 \mathrm{~mm}$; wing $3.2 \mathrm{~mm}$.

HEAD. Ocellar bristles very long. Verticals minute. Postocular bristles short, uniseriate throughout, black above, white below. Antenna with postpedicel clear yellow, rounded, but with pointed tip. Palpus orange, with small black marginal bristles only.

THORAX. Subshining, bluish black. Five very short dorsocentral bristles. Humeral minute, a long pre-alar and a long supra-alar, a pair of long scutellars.

Colour of Legs. Dusky yellowish brown. All coxae black. Femora darker near base. Tarsomeres with a colour pattern.

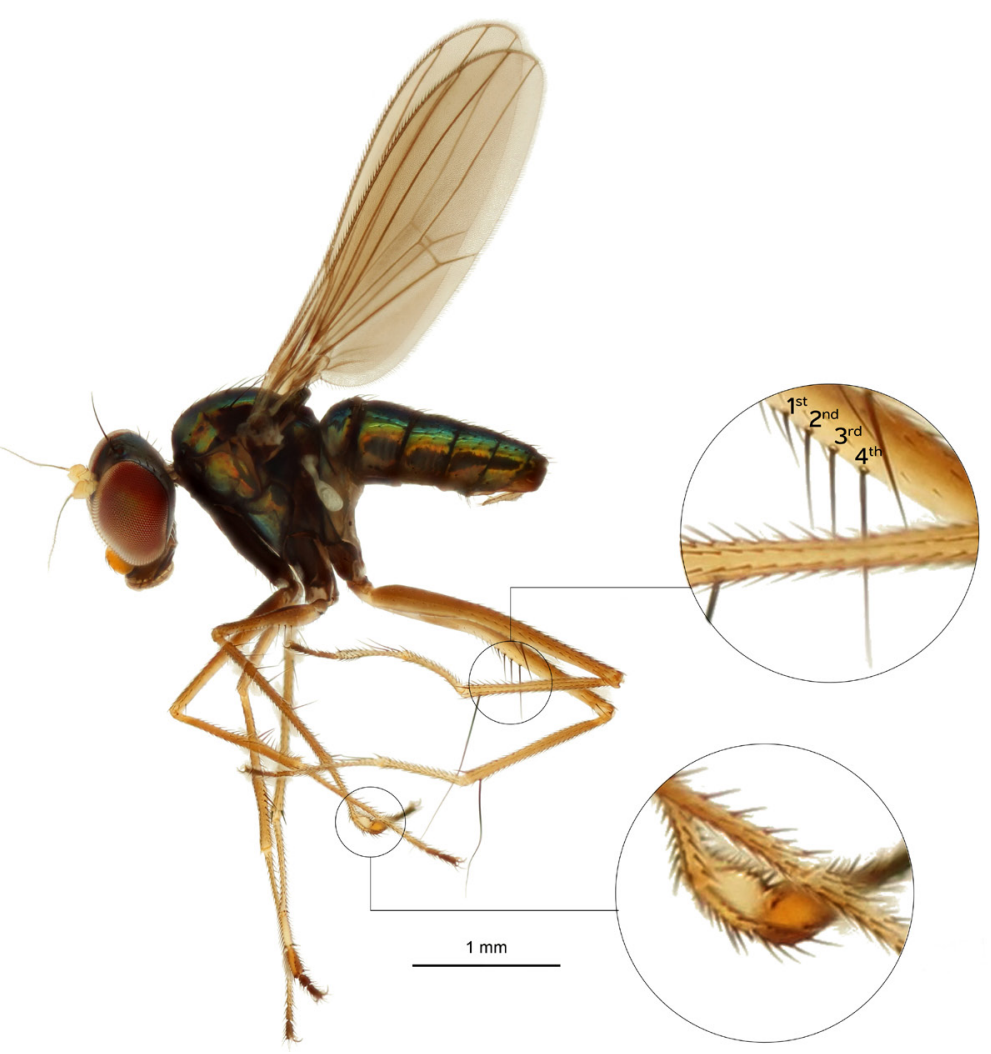

Fig. 8. Thinophilus subapicalis Samoh \& Grootaert sp. nov. Male habitus (Abdulloh Samoh leg., PSUNHM (PSUZCDIP0015)). 
FORE LEG. Coxa with short black bristles. Femur club-shaped at base, ventrally with several minute bristles. Tibia with a ventral swelling just beyond middle, with a row of short ventral bristles over entire length, but at the swelling with two long bristles (Fig. 8). Tarsomere 1 longer than following four tarsomeres combined; ventrally with a row of interspaced bristles, a little longer than the width of the tarsomere. Tarsomeres 4 and 5 darkened.

MID LEG. Coxa without exterior bristle. Femur even more club-shaped than fore femur; base more swollen and apical portion thinner; with a row of long ventral bristles; longest near middle of femur. Mid tibia longer than mid femur with five interspaced long ventrals, being at least three times as long as tibia width. Tarsomere 1 much longer than the four apical tarsomeres combined. Tarsomere 2 ventrally flattened, ventrally pale yellowish. Tarsomere 3 ventrally also flattened, orange; dorsally covered with dense short black bristles (Fig. 8, inset). Tarsomeres 4 and 5 darkened.

HIND LEG. Coxa with a fine exterior bristle. Femur in basal half spindle-shaped (not so pronounced clubshaped as in the fore and mid femora), but dorsoventrally curved. Just beyond middle with a comb of three long ventral bristles, with a few tiny bristles anteroventrally (Fig. 8, inset). Tibia much shorter than femur, with a long dorsal pre-apical bristle that is at least as long as the tibia. Tarsomere 1 and 2 long, subequal in length. Tarsomere 2 with two very long ventral bristles near base. Tarsomeres 3,4 , and 5 darkened.

WING. Elongate, brownish tinged with brown veins. Squama whitish with pale cilia. Haltere white.

AвDOMEN. Subshining black with a bluish shine. Tergite 1 with longer apical bristles than the following tergites. Sternite 4 with some long apical bristles. Terminalia (Fig. 10). Cerci pale dusky yellowish,

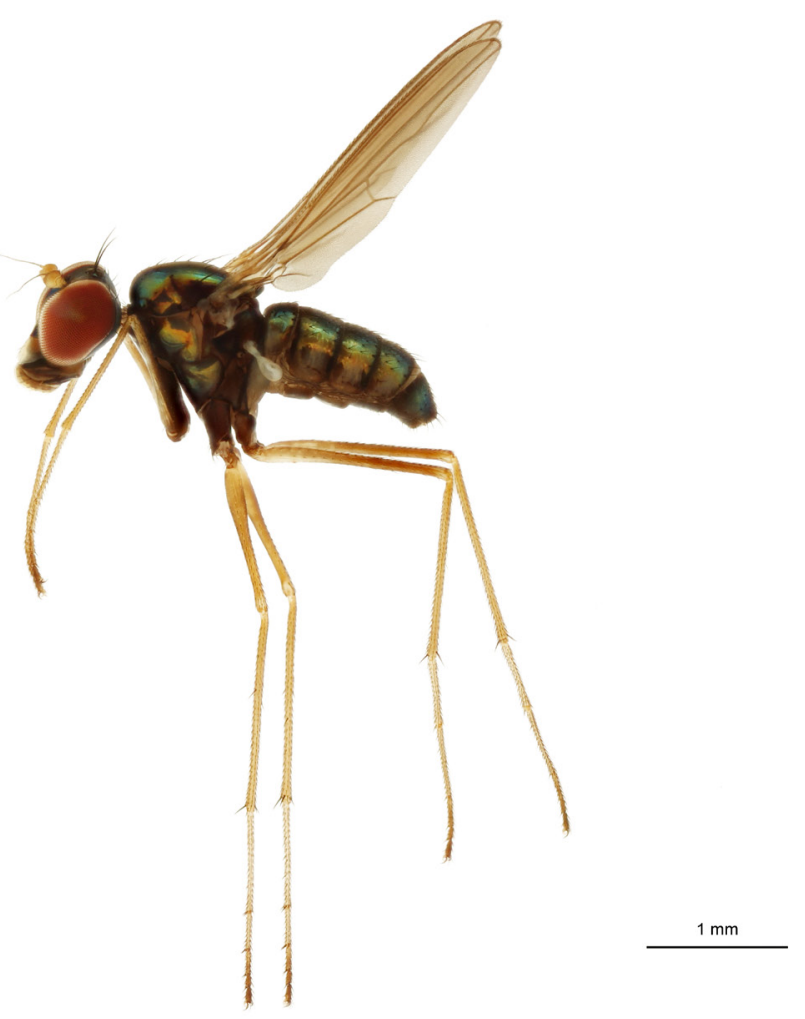

Fig. 9. Thinophilus subapicalis Samoh \& Grootaert sp. nov. Female habitus (Abdulloh Samoh leg., PSUNHM (PSUZCDIP0016)). 
dorsally fused over the entire length, only tips of both cerci free (Fig. 10C). Surstylus with spoonshaped apex, lacking bristles. A set of three ventral bristles near middle. A short epandrial bristle present (Fig. 10A-B).

Female (Fig. 6)

Body $2.9 \mathrm{~mm}$; wing $2.9 \mathrm{~mm}$. Similar to male. Palpus silvery white. All legs simple. Femora indistinctly club-shaped. Bristling on legs minute.

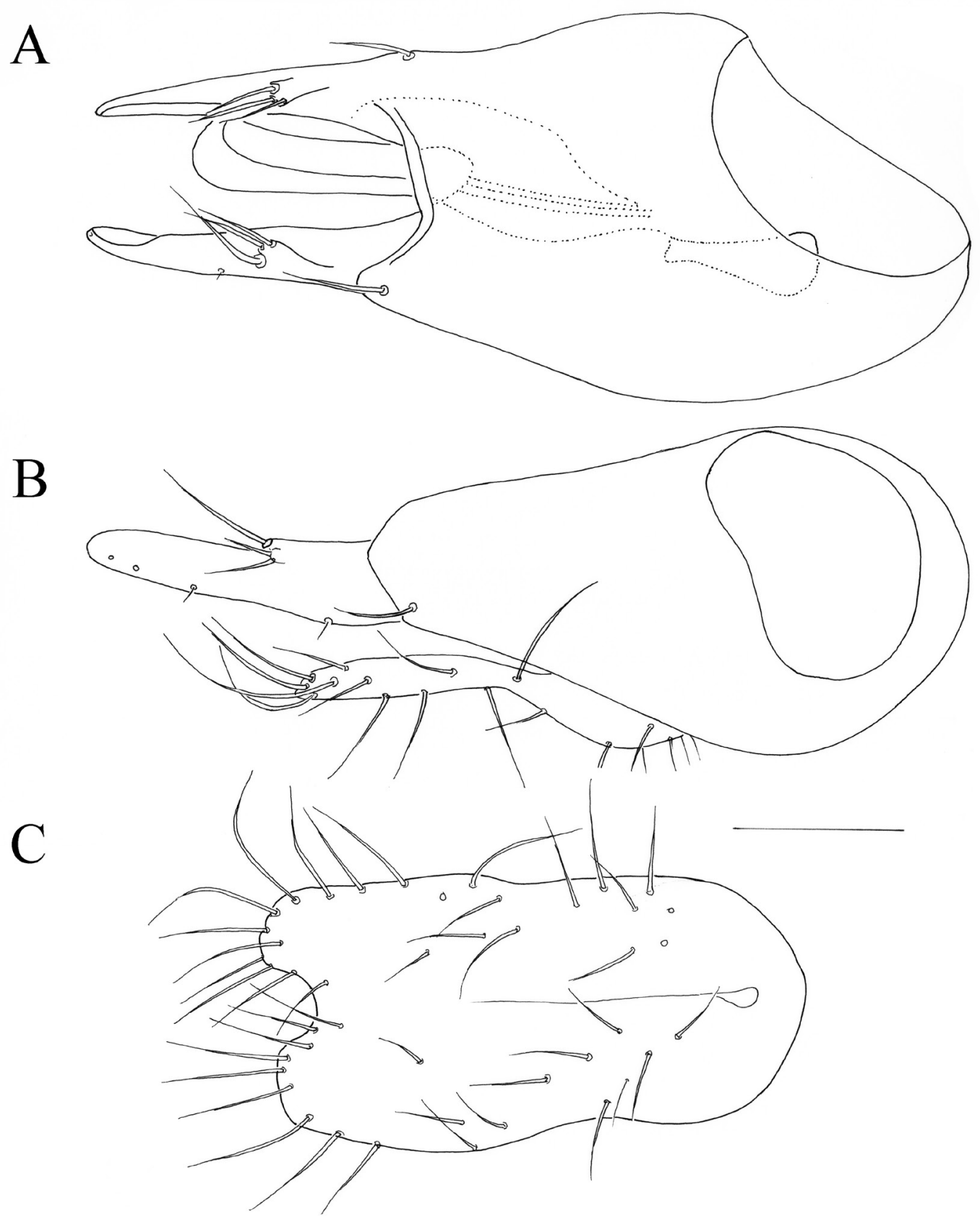

Fig. 10. Thinophilus subapicalis Samoh \& Grootaert sp. nov. Male terminalia (Abdulloh Samoh leg., PSUNHM (PSUZCDIP0015)). A. Ventral view of hypopygium. B. Lateral view. C. Dorsal view of cerci. Scale $=0.1 \mathrm{~mm}$. 


\section{Comments}

The new species is closely related to T. superbus Grootaert, 2018. It differs in many of the male secondary sexual characters of the bristling of the legs. Very obvious is the swelling just beyond the middle of the fore tibia that bears a few long ventral bristles. There is no such swelling in T. superbus. The mid femur has long ventral bristles just beyond the basal swelling and the mid tibia has long, interspaced ventral bristles in the new species. No such bristles are present in T. superbus. The long bristle on the hind tibia is in a more apical position in T. superbus, while distinctly pre-apical in the new species. Thinophilus superbus has several very long dorsal bristles on hind tarsomere 2 , and also long dorsals on tarsomeres 3,4 , and 5 . The new species lacks these bristles.

\section{New records of marine Thinophilus in peninsular Thailand}

Twelve species of the genus Thinophilus have been reported from Thailand so far (Grootaert \& Meuffels 2001; Grootaert 2017; Samoh et al. 2017). Here, we report on ten species of marine Thinophilus from southern Thailand for the first time, though some records have already been mentioned without any detail in Grootaert (2018). Including the three new species described above, the total number of species for Thailand now amounts to 25 species

Thinophilus apicatus Grootaert, 2018

\section{Material examined}

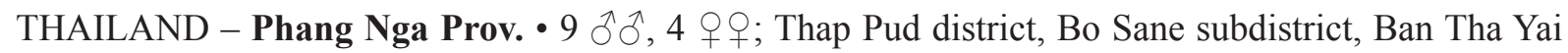
Pier; 8²6'46.6" N, 98³6'22.1" E; 13 Feb. 2015; A. Samoh leg.; sweep netting; PSUNHM • $14 \delta^{\widehat{\partial}} \delta^{\top}$, 4 우; Takua Pa district, Bang Nai Si subdistrict, Ban Bang Nai Sang; 854'26.3" N, 98²4'00.5" E; 11 Feb. 2015; A. Samoh leg.; sweep netting; PSUNHM. - Krabi Prov. 2 ô $\widehat{\jmath}$; Khlong Thom district, Khlong Phon; 748'11.6" N, 99¹0'11.7" E; 13 Jun. 2015; A. Samoh leg.; sweep netting; PSUNHM

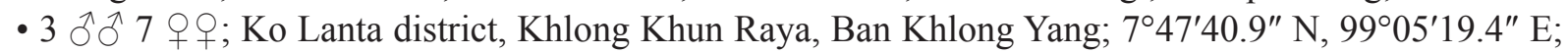
13 Jun. 2015; A. Samoh leg.; sweep netting, PSUNHM. - Chumphon Prov.・19 ठ̊ district, Tha Yang subdistrict, Ban Elet; $10^{\circ} 22^{\prime 2} 24.0^{\prime \prime}$ N, 99²13'35.2" E; 18 Feb. 2015; A. Samoh leg.; sweep netting; PSUNHM.

\section{Distribution}

Andaman Sea (Phang Nga Province) and Gulf of Thailand (Chumphon Province).

Thinophilus chaetulosus Grootaert, 2018

\section{Material examined}

THAILAND - Songkhla Prov. • $16 \widehat{\partial} \widehat{\partial}, 7$ $q \propto$; Laem Pho, Khu Tao, Hat Yai; $7^{\circ} 09^{\prime} 12.3^{\prime \prime}$ N,

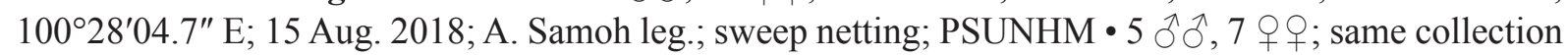
data as for preceding; $7^{\circ} 09^{\prime} 12.3^{\prime \prime} \mathrm{N}, 100^{\circ} 28^{\prime} 04.7^{\prime \prime} \mathrm{E}$; 27 Jun. 2015; PSUNHM.

\section{Distribution}

Gulf of Thailand (Songkhla Province).

Thinophilus clavatus Zhu, Yang \& Masunaga, 2006

\section{Material examined}

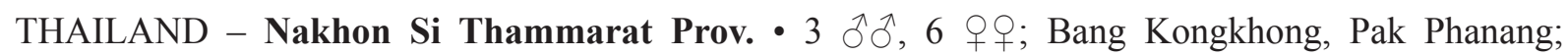
$8^{\circ} 24^{\prime} 08.9^{\prime \prime}$ N, 100¹1'17.2" E; 1 May 2015; A. Samoh leg.; sweep netting; PSUNHM・ 1 đ, 2 o $\circ$; Pak 
Phanang Tawantok, Pak Phanang; 8²2'30.0" N, 100¹0'00.4" E; 30 Apr. 2015; A. Samoh leg.; sweep netting; PSUNHM • 5 q 9 ; Talumpuk Cape, Pak Phanang; 8³1'06.6" N, 10006'51.5" E; 2 May 2015;

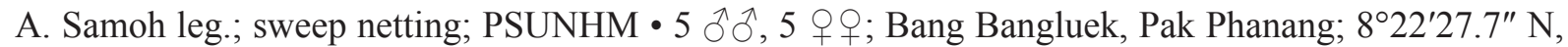

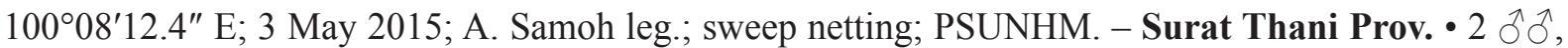
2 우; Khlong Thonglang, Khlong Chanak, Muang; 9¹2'01.9" N, 99²1'20.4" E; 6 Jul. 2018; A. Samoh leg.; sweep netting; PSUNHM.

\section{Distribution}

Gulf of Thailand (Nakhon Si Thammarat, Surat Thani, and Songkhla Provinces). Further known from China and Singapore.

\section{Comments}

This robust species is closely related to T. chaetulosus and quite common in southern Thailand. It is not strictly marine and thus often found at some distance from the sea. Recently, it was also recorded on Pulau Ubin, an island on the North West coast of Singapore (P. Grootaert, unpublished).

Thinophilus evenhuisi Grootaert, 2018

\section{Material examined}

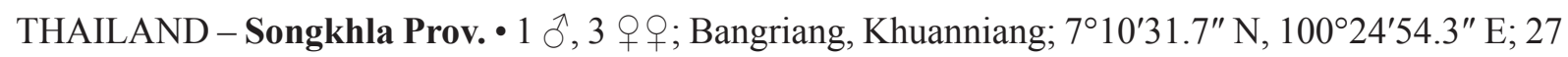
Jul. 2018; A. Samoh leg.; hand collecting and sweep netting; PSUNHM.

\section{Distribution}

Gulf of Thailand (Songkhla Province).

\section{Comments}

A very rare species described recently from Singapore, where it was found only once in 2005 and never after despite more intensive sampling (Grootaert 2018).

Thinophilus lenachanae Grootaert, 2018

\section{Material examined}

THAILAND - Ranong Prov. • 1 क; Khlong La-Un, Bangkaew, La-Un; 10¹0'25.7" N, 98 43'01.9" E; 11 Jul. 2018; A. Samoh leg.; hand collecting and sweep netting; PSUNHM • $17 \widehat{\partial} \partial^{\lambda}, 14$ q 9 ; Khlong Lad Nod, Muang Klang, Kapoe; 9³5'27.9" N, 98³1'12.1" E; 12 Jul. 2018; A. Samoh leg.; hand collecting and sweep netting; PSUNHM.

\section{Distribution}

Andaman Sea (Ranong Province).

\section{Comments}

This species is also rare in Singapore.

Thinophilus longicilia Evenhuis \& Grootaert, 2002

\section{Material examined}

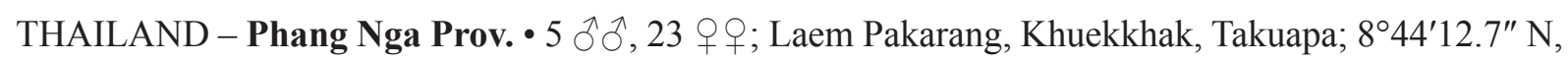
98¹3'13.1" E; 28 Jul. 2018; A. Samoh leg.; hand collecting and sweep netting; PSUNHM. 


\section{Distribution}

Andaman Sea (Phang Nga province).

\section{Comments}

With reference to a study by Grootaert (2018), this species was collected from several mangroves and beaches at low tide in Singapore such as Lim Chu Kang, Sungei Buloh, and Mandai mangroves. In the present study, the first author mainly observed and sampled this marvellous long-legged fly with its long bristles fore and mid legs on a rocky beach at Laem Pakarang in Phang Nga province, southern Thailand during low tide and in areas exposed to the sun.

Thinophilus nigrilineatus Grootaert, 2018

\section{Material examined}

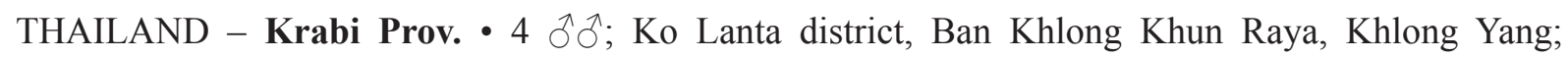
747'40.9" N, 9905'19.4" E; 26 Feb. 2015; A. Samoh leg.; sweep netting; PSUNHM • 2 ठิ ô; Ko Lanta district, Siri Lanta Bridge, Ko Lantayai, Saladan; 7³8'43.0" N, 9902'42.8" E; 26 Feb. 2018; A. Samoh leg.; sweep netting; PSUNHM. - Phang Nga Prov.• 1 q; Ban Tha Yai Pier, Bo Sane, Thap Pud; $8^{\circ} 26^{\prime} 46.6^{\prime \prime}$ N, 98³6'22.1" E; 15 Jul. 2018; A. Samoh leg.; sweep netting; PSUNHM.

\section{Distribution}

Andaman Sea (Krabi and Phang Nga Provinces).

\section{Comments}

This species is also rare in Singapore where it was described from Semakau Island, an island south of the main island of Singapore. In a new survey of mangroves in Singapore from March to June 2018, a single male was found along Belayer Creek (P. Grootaert, unpublished).

Thinophilus superbus Grootaert, 2018

\section{Material examined}

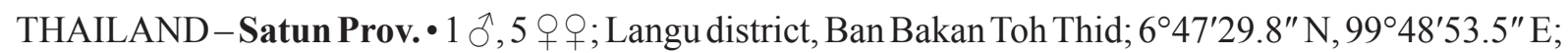

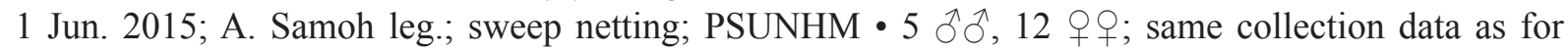

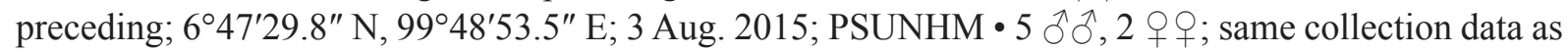

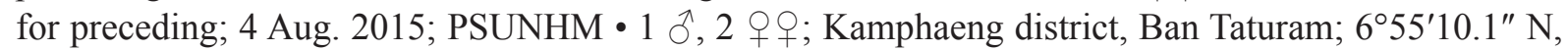
9943'59.0" E; 4 Aug. 2015; A. Samoh leg.; sweep netting; PSUNHM.

\section{Distribution}

Andaman Sea (Satun Province).

\section{Comments}

Apart from the above records this elegant species is still only know from its type locality Semakau Island, an island south of Singapore.

Thinophilus simplex Grootaert, 2018

\section{Material examined}

THAILAND - Krabi Prov. • $3 \hat{\jmath} \widehat{\partial}, 1$ 9 ; Khlong Thom district, Khlong Phon; 7048'11.6" N,

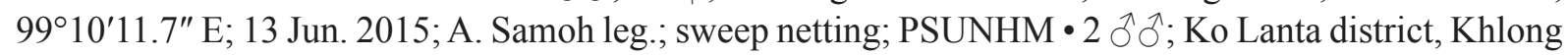


Yang subdistrict, Khlong Khun Raya; 747'40.9" N, 9905'19.4" E; 26 Feb. 2015; A. Samoh leg.; sweep netting; PSUNHM. - Phang Nga Prov. 6 ổ, 9 o $O$; Thap Pud district, Bo Sane subdistrict, Ban Tha Yai Pier; 8²6'46.6" N, 98³6'22.1" E; 13 Feb. 2015; A. Samoh leg.; sweep netting; PSUNHM • 1 万, 2 우; Takua Pa district, Bang Nai Si; 854'26.3" N, 98²4'00.5" E; 11 Feb. 2015; A. Samoh leg.; sweep

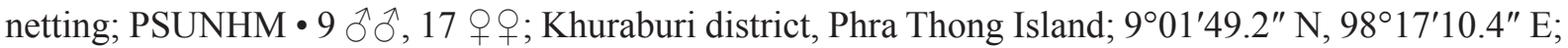
26 Apr. 2018; A. Samoh leg.; sweep netting; PSUNHM. - Satun Prov. 4 우; Langu district, Pakbara; 650'28.7" N, 9946'33.4" E; 1 Jun. 2015; A. Samoh leg.; sweep netting; PSUNHM.

\section{Distribution}

Andaman Sea (Krabi, Phang Nga, and Satun Provinces).

\section{Comments}

This species is the most common species of Thinophilus in Singapore (Grootaert 2018).

Thinophilus yeoi Grootaert, 2018

\section{Material examined}

THAILAND - Surat Thani Prov. $\bullet 28 \hat{\jmath}, 41$ + $\circ$; Chai Ya district, Phum Riang subdistrict, Ban Nua

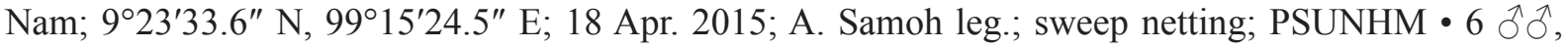
6 우; Mueang district, Khlong Chanak subdistrict, Khlong Thonglang; 9¹2'01.9" N, 99²1'20.4" E; 18 Jul. 2018; A. Samoh leg.; sweep netting; PSUNHM. - Chumphon Prov. 6 ô $\widehat{o}, 2$ 우; Sawee district, Dan Sawee; 10¹6'41.2" N, 9909'43.5" E; 7 Jul. 2018; A. Samoh leg.; sweep netting; PSUNHM.

\section{Distribution}

Gulf of Thailand (Surat Thani and Chumphon Provinces).

\section{Comments}

Apart from Singapore and Thailand this species is also known from Brunei.

\section{Discussion}

By adding three new species for science and ten first records to the fauna of southern Thailand, we confirm the regional endemism of species and species groups of Thinophilus in Southeast Asia (Grootaert 2018).

As can be seen in Table 1, four species are found on both the coasts of the Andaman Sea and the Gulf of Thailand. Thinophilus setiventris and T. nitens are rather terrestrial species living near freshwater bodies and only occasionally found in mangroves (Grootaert 2018). They have a wide distribution in Southeast Asia. Thinophilus minutus and T. apicatus, which are supposed to be true mangrove species, also occur on both sides of peninsular Thailand.

Seventeen species are recorded from the coasts of the Andaman Sea and thirteen of these are only known from this region up to now. Eleven species are found on the coasts of the Gulf of Thailand, seven being exclusive for this region.

The marine Thinophilus of the Andaman Sea coasts are thus more diverse. It is also remarkable that three groups of sister species occur in peninsular Thailand. The sister species T. spinatus $-T$. spinatoides, and T. superbus-T. subapicalis are exclusive for the Andaman Sea, while in the couple T. parmatus - . parmatoides, T. parmatoides is only known from the Gulf of Thailand. Each species is morphologically very similar to its sister species but with distinct male secondary sexual characters. Moreover, they all belong to the 'Thinophilus spinatus-group' sensu Grootaert (2018). This points to a 
Table 1. Thinophilus Wahlberg, 1844 occurring in peninsular Thailand. Comparison of the species along the Andaman Sea coast, the Gulf of Thailand, and the intersection of both seas at the level of Singapore.

\begin{tabular}{|c|c|c|c|}
\hline Species & $\begin{array}{l}\text { Andaman } \\
\text { Sea }\end{array}$ & $\begin{array}{c}\text { Gulf of } \\
\text { Thailand }\end{array}$ & $\begin{array}{c}\text { Singapore at the } \\
\text { intersection }\end{array}$ \\
\hline T. apicatus Grootaert, 2018 & 1 & 1 & 1 \\
\hline T. boonrotpongi Samoh et al., 2017 & 1 & & \\
\hline T. chaetulosus Grootaert, 2018 & & 1 & 1 \\
\hline T. clavatus Zhu et al., 2006 & & 1 & 1 \\
\hline T. evenhuisi Grootaert, 2018 & & 1 & 1 \\
\hline T. inaequalis Samoh \& Grootaert sp. nov. & 1 & & \\
\hline T. langkawensis Samoh et al., 2017 & 1 & & \\
\hline T. lenachanae Grootaert, 2018 & 1 & & 1 \\
\hline T. longicilia Evenhuis \& Grootaert, 2002 & 1 & & 1 \\
\hline T. minutus Samoh et al., 2017 & 1 & 1 & \\
\hline T. nigrilineatus Grootaert, 2018 & 1 & & 1 \\
\hline T. nitens Grootaert \& Meuffels, 2001 & 1 & 1 & \\
\hline T. parmatoides Samoh et al., 2017 & & 1 & \\
\hline T. parmatus Grootaert \& Meuffels, 2001 & 1 & & \\
\hline T. parvulus Samoh et al., 2017 & & 1 & \\
\hline T. plektron Samoh \& Grootaert sp. nov. & 1 & & \\
\hline T. setiventris Grootaert \& Meuffels, 2001 & 1 & 1 & \\
\hline T. simplex Grootaert, 2018 & 1 & & 1 \\
\hline T. spinatoides Samoh et al., 2017 & 1 & & \\
\hline T. spinatus Samoh et al., 2017 & 1 & & 1 \\
\hline T. subapicalis Samoh \& Grootaert sp. nov. & 1 & & \\
\hline T. superbus Grootaert, 2018 & 1 & & 1 \\
\hline T. variabilis Samoh et al., 2017 & & 1 & 1 \\
\hline T. yeoi Grootaert, 2018 & & 1 & 1 \\
\hline Total & 17 & 11 & 12 \\
\hline
\end{tabular}

peculiar speciation process that might have been allopatric at first and later on became mixed up again. Apparently, this happened mainly along the coast of the Andaman Sea.

Southern Thailand has twelve species in common with Singapore, which is half the number of species occurring in Thailand. This means that there is quite a species turnover between Thailand and Singapore, the latter situated at the tip of the Malay peninsula. Singapore is the first area where the Andaman Sea meets the South China Sea. This geographical location probably explains why the fauna of Singapore, counting twenty one species, is so diverse on such a small surface. Haplotype network studies might elucidate the patterns of diversity.

\section{Acknowledgements}

This study was partially funded by the faculty of Science, Prince of Songkla University. We also thank Dr. Pipat Soisuk (who holds the funding "Plant Genetic Conservation Project under her Royal Highness Princess Maha Chakri Sirindhorn, project no. SCI600085S") for taking the first author to join his field trip to Koh Phra Thong several times. 


\section{References}

Brecko J., Mathys A., Dekoninck W., Leponce M., Vandenspiegel D. \& Semal P. 2014. Focus stacking: Comparing commercial top-end set-ups with a semi-automatic low budget approach. A possible solution for mass digitization of type specimens. Zookeys 464: 1-23. https://doi.org/10.3897/zookeys.464.8615

Evenhuis N. \& Grootaert P. 2002. Annotated checklist of the Dolichopodidae (Diptera) of Singapore, with a description of a new genus and species. The Raffles Bulletin of Zoology 50 (2): 301-316.

Grootaert P. 2017. A new Thinophilus Wahlberg from the river banks of the Mekong river in Thailand (Diptera : Dolichopodidae). Tropical Natural History 17 (2): 88-93.

Grootaert P. 2018. Revision of the genus Thinophilus Wahlberg (Diptera: Dolichopodidae) from Singapore and adjacent regions: A long term study with a prudent reconciliation of a genetic to a classic morphological approach. Raffles Bulletin of Zoology 66: 413-473.

Grootaert P. \& Meuffels H. 2001. Notes on marine dolichopodid flies from Thailand (Insecta: Diptera: Dolichopodidae). The Raffles Bulletin of Zoology 49 (2): 339-353.

Negrobov O.P., Maslova O.O. \& Selivanova O.V. 2016. The genus Thinophilus Wahlberg, 1844 (Diptera, Dolichopodidae) from Eastern Palaearctic, with description of two new species and new records. Acta Zoologica Academiae Scientiarum Hungaricae 62 (2): 143-151. https://doi.org/10.17109/AZH.62.2.143.2016

Puniamoorthy N., Rifqi M., Tan D. \& Meier R. 2009. From kissing to belly stridulation: Comparative analysis reveals surprising diversity, rapid evolution, and much homoplasy in the mating behavior of 27 species of sepsid flies (Diptera: Sepsidae). Journal of Evolutionary Biology 22 (11): 2146-2156. https://doi.org/10.1111/j.1420-9101.2009.01826.x

Samoh A., Boonrotpong S. \& Grootaert P. 2015. Ngirhaphium Evenhuis \& Grootaert from South Thailand (Diptera: Dolichopodidae) with the description of a new species. Zootaxa 3946 (1): 125-132. https://doi.org/10.11646/zootaxa.3946.1.6

Samoh A., Satasook C. \& Grootaert P. 2017. Eight new species of marine dolichopodid flies of Thinophilus Wahlberg, 1844 (Diptera: Dolichopodidae) from peninsular Thailand. European Journal of Taxonomy 329: 1-40. https://doi.org/10.5852/ejt.2017.329

Manuscript received: 11 September 2018

Manuscript accepted: 4 February 2019

Published on: 12 March 2019

Topic editor: Gavin Broad

Desk editor: Alejandro Quintanar

Printed versions of all papers are also deposited in the libraries of the institutes that are members of the EJT consortium: Muséum national d'Histoire naturelle, Paris, France; Meise Botanic Garden, Belgium; Royal Museum for Central Africa, Tervuren, Belgium; Royal Belgian Institute of Natural Sciences, Brussels, Belgium; Natural History Museum of Denmark, Copenhagen, Denmark; Naturalis Biodiversity Center, Leiden, the Netherlands; Museo Nacional de Ciencias Naturales-CSIC, Madrid, Spain; Real Jardín Botánico de Madrid CSIC, Madrid, Spain; Zoological Research Museum Alexander Koenig, Bonn, Germany. 